\section{Ivana Kronja}

Visoka škola likovnih i

primenjenih umetnosti

strukovnih studija

Beograd, Srbija

i.kronja@yahoo.com.
DOI: https://doi.org/10.18485/slovenika.2018.4.1.5

UDK: 791.2(497.4)"199/..."

791.6(497.4)"199/..."

\title{
Neke autorske tendencije $u$ savremenom slovenačkom filmu: nostalgija, kritika, angažman
}

\section{Sažetak}

Naučniogled na temu „Nekeautorsketendencijeu savremenom slovenačkom filmu“ bavi se odabranim filmskim ostvarenjima iz recentne slovenačke filmske produkcije (od kraja 1990-ih do danas), uključujući dokumentarni i igrani film. Cilj rada je da istraži tematske, poetske i stilske tendencije u savremenom slovenačkom autorskom filmu, tj. u filmskoj umetnosti, koja se razvija i dostiže zavidan nivo profesionalizma u produkciji i filmskoj estetici danas. U pogledu tematike i stilistike, savremeni slovenački film odlikuje preispitivanje prošlosti i tranzicionih socijalnih tema, kojima se neretko pristupa $u$ visoko estetizovanom autorskom / postmodernom ključu, ili pak kroz neomodernističku poetiku.

Ključne reči: slovenačka kinematografija, nostalgija, angažman, socijalni horor, filmski stil

\section{Uvod}

Nakon raspada SFRJ, jugoslovenska kinematografija segmentira se na nacionalne kinematografije nekadašnjih jugoslovenskih republika, koje se razvijaju u skladu sa ekonomskim, političkim i kulturnim prilikama novonastalih zemalja. Kao samostalna država od 1991. i članica Evropske Unije od 2004, Slovenija je već tokom prve polovine devedesetih godina prošlog veka, budući da je izbegla dugotrajan rat na svojoj teritoriji i ozbiljne međunacionalne konflikte, 
uspostavila filmske institucije srodne onima u severnoevropskim demokratijama - ističe Jurica Pavičić (Pavičić 2011, 31). Godine 1994. formira se Filmski sklad Republike Slovenije, kao javni fond koji preuzima svu imovinu producentske kuće Vesna film, a finansira se iz budžeta, dok se nacionalni filmski studio Viba film, nakon izvesne pause, obnavlja kao tehnička baza (Pavičić 2011, 31). „U skladu s pomalo etatističkim karakterom slovenske tranzicije u kojoj je postojala određena rezerva spram nagle privatizacije i liberalizacije, kinematografija je ipak ostala $u$ velikoj mjeri pod kontrolom države." (Pavičić 2011, 32).

Slovenačka kinematografija danas ostvaruje visoke standarde $\mathrm{u}$ drami, filmskoj fotografiji, u društvenoj angažovanosti i u prenošenju kulturnih i prirodnih specifičnosti svoga podneblja. Istorija ove kinematografije uključuje značajne pionire: dr Karela Grosmana, Veličana Beštera, Metoda i Milku Bađuru, te međuratne režisere Ferda Delaka, Janka Ravnika, Marija Foerstera i filmskog autora i publicistu Bratka Krefta, ${ }^{1}$ kao i noseće ličnosti jugoslovenskog revolucionarnog i autorskog filma: Franca Štiglica, Matjaža Klopčiča, Boštjana Hladnika, Joža Pogačnika, Karpa Godinu, ali i ne manje značajne, izuzetne glumačke ličnosti, kao što su Ita Rina, Milena Zupančič, Sava Severova, Polde Bibič, Radko Polič i mnogi drugi. Kako ističe Sergij Grmek Germani, važne smernice u slovenačkim filmovima tokom devedesetih godina bile su u velikoj meri povezane sa starijim karakteristikama ove kinematografije: „I slovenački film može da se razvija i menja samo ako shvata tradiciju i na nju se nadovezuje, što može da mu omogućava individualizaciju i u međunarodnom kontekstu. A to ne znači traženje nečega čisto slovenačkog u filmu, a još manje zanemarivanje onoga što se u prošlosti dogradilo kao jugoslovenski film“ (Germani 2002, 5).

U pogledu tematike i stilistike, savremeni slovenački film odlikuje preispitivanje prošlosti i tranzicionih socijalnih tema, kojima se neretko pristupa $u$ visoko estetizovanom autorskom ključu - postmodernističkom ili neomodernističkom. Najsavremenija ostvarenja Martina Turka, Marka Naberšnika, Borisa Jurjaševiča i drugih svedoče o društvenim promenama izazvanim neoliberalnim kapitalističkim poretkom i psihologijom masovnog potrošačkog društva, te o uticaju politike i ekonomije na život običnih ljudi. Socijalni / istorijski dokumentarizam jakog autorskog i ekološkog pečata prisutan je u delima Metoda Peveca, Mihe Čelara, Bojana Laboviča, Matja-

\footnotetext{
${ }^{1}$ Videti poglavlje o Sloveniji u knjizi dr Dejana Kosanovića Kinematografija i film $u$ Kraljevini SHS/Kraljevini Jugoslaviji, 1918-1941., str. 110-114.
} 
ža Ivanišina, Borisa Petkoviča itd. Ipak, važno je istaći da filmovi o mladima i porodične drame bez naglašenog društvenog konflikta, sa pre svega akcentovanim kulturološkim vrednostima i vrednostima prirodne sredine prekrasnog slovenačkog podneblja, predstavljaju dobar deo ove kinematografije, njenu „mejnstrim“ karakteristiku. Iako manjinska, kao stabilna linija u okviru poetike slovenačkog filma izdvaja se i tendencija art-filma, koji kombinuje igrani i eksperimentalni film, video-art, te uticaje savremenog plesnog teatra (Rudi Urban, Vlado Škafar, Branko Potočan, Saša Podgorček).

Kontekst efekata neoliberalizacije slovenačkog društva pokazuje se kao veoma važan za slovenačku kinematografiju, generišući najveći broj tema u njenoj novijoj produkciji, od kraja 1990-ih do danas. Prosvećene demokratske tendencije, kao trajna odlika slovenačke kulture, stila života i sistema vrednosti u posleratnom periodu, sada se sudaraju sa onim posledicama svetskog neoliberalizma koje udaraju u samu njihovu srž: sa krajem socijalne države i zaoštravanjem klasnih razlika, sa poništavanjem specifičnosti i bogatstva lokalnih kultura i običaja, te sa duboko nepravednim prekarijatskim konceptom prava na rad.

Kao simptom ovog sudara pojavljuju se i raznoliki koncepti angažmana u slovenačkom filmu. Angažovanost slovenačkih autora $i$ autorki nastavlja razradu pitanja demokratizacije i individualizma, koji stoje nasuprot tradicionalizmu i političkom autoritarizmu $\mathrm{u}$ ovim aktuelnim, promenjenim uslovima - $\mathrm{u}$ dobu pada socijalizma i uvođenja prekarijatske eksploatacije. Kritički autorski film u Sloveniji danas najpre polazi od stanovišta da je filmski medij važno i uticajno sredstvo društvene komunikacije. Nudeći oštro preispitivanje birokratske i klasne prirode društvenih odnosa, sa učestalim fokusom na problemima elitizma i kulturne diskriminacije „drugih“ unutar sopstvenog društva, uključujući u nekim slučajevima i temu rodne ravnopravnosti, savremeni slovenački autorski film pokazao se kao izraz i nosilac težnji ka bogatijem nacionalnom kulturnom integritetu i humanijem društvu.

Motiv „jugonostalgije“, kao „osećanje tuge i žaljenja koje se javlja kod osoba otrgnutih od zavičaja“ (Poro 1990, 429), pokazuje se, sasvim prirodno, kao sastavni deo umetničkih uopšte, pa tako i filmskih stremljenja u zemljama koje nose manju ili veću traumu raspada SFR Jugoslavije. „Emocionalne i estetičke konotacije nostalgičnog osećanja snažno su nadahnule čitavu jednu struju u umetničkom stvaranju koja je dostigla vrhunac sa romantizmom“ (Poro 1990, 429). U savremenoj književnosti i filmu, motiv nostal- 
gije povezan je, pak, sa ideološkom i političkom kritikom ratovima izazvanih migracija, raspada država i kulturnih prostora, a može se javiti i u vidu svojevrsnog eskapizma. Ljiljana Šop predlaže kritičko prevrednovanje nostalgije u odnosu na tradicionalno shvatanje ovog pojma:

„(...) Odavno je jasno da je nostalgija u modernim vremenima mnogo širi pojam pod kojim se uglavnom podrazumeva vremenska a ne prostorna čežnja, te da fluidnost nostalgije obuhvata čitav spektar pojmova, simbola, predmeta, zvukova, mirisa, ukusa koji najavljuju mogućnost nostalgičnog osećanja kakvo može, ali sve češće i ne mora da ima vezu sa rodnom grudom kao takvom. Pojam nostalgije se, po mom osećanju, ne samo pomerio nego u mnogo čemu i sasvim izmestio iz svog prvobitnog značenja, označavajući čežnju za različitim periodima, mestima, duhovnim ili materijalnim činiocima odživljene prošlosti koja je, po sudu nostalgičara, bila intenzivnija, lepša, bolja, srećnija, sadržajnija, ili barem podnošljivija od sadašnjosti. A verovatno nije bila, samo što je tada nostalgičar bio mlađi, neiskusniji, naivniji i neviniji, snažniji i energičniji, te sada više čezne za sobom nekadašnjim nego za konkretnim vremenom (istorijskim i društvenim) i prostorom u kojem se život za kojim žali i čezne odvijao. Nostalgija je potreba za zaustavljanjem vremena, stoga je može osećati i mlad čovek koji živi u mestu gde je rođen, već samo stoga što se minimalni prostor iz najranijih sećanja prebrzo promenio (park za igru ume da osvane kao bezbojni stambeni blok $\mathrm{u}$ kojem nikoga ne poznajete). (...) Nostalgiju izaziva svaki pad u stvarnost, ali je ne leči ni jedan izmaštani raj" (Šop 2010, 217-219).

Nostalgija ka prošlosti, uključujući tu kako istorijsku i građansku prošlost pre epohe komunizma, koja se ponovo otkriva u bivšim socijalističkim zemljama, tako i jugoslovensko socijalističko društveno i kulturno nasleđe, $u$ okviru slovenačke kinematografije zauzima specifično mesto. Čini se da slovenački autori i autorke, osim klasične nostalgije, koja pre svega sadrži kulturalno određenje, danas nastoje da uspostave trezven i kritički odnos prema (jugo)nostalgiji kao kulturološkoj, društveno-političkoj i filozofskoj kategoriji.

U daljem tekstu izdvojićemo nekoliko karakterističnih primera artikulacije autorskih rukopisa u savremenom slovenačkom filmu, koja se kreće od kulture sećanja i nostalgije do društvenog i rodnog angažmana i kritike nostalgije, a za koje verujemo da izvanredno reprezentuju kako deo estetičkih tendencija unutar ove kinematografije, tako i društvene odgovore na ova važna i kompleksna pitanja. 


\section{Kronja \\ Neke autorske tendencije $u$...}

\section{Nostalgija i grad: Ljubljana je voljena (2005)}

Kao paradigma klasične nostalgije mogu se uzeti filmovi u kojima je grad, sa smenom epoha i bogatom istorijom kulture, glavna „ličnost" filmske pripovesti. Nad gradom se smenjuju i prolaze manje ili više mračne vladavine, ratovi, promene načina života i vrednosnog poretka, ali on ipak čuva svoju unutrašnju bit. Arhitektura i struktura urbane naseobine, zajedno sa istorijskim i emotivnim sećanjem stanovništva, jesu i ostaju njegova suština, duša grada. Izuzetan primer ovakvog pristupa nostalgiji na filmu predstavlja testamentarno delo majstora filmske režije Matjaža Klopčiča (1934-2007) Ljubljana je voljena (Ljubljana je ljubljena, 2005²). Prema rečima Andreja Špraha, „Matjaž Klopčič se u Ljubljani iznova vraća pitanjima prolaznosti, koja su u njegovom velikom opusu uvek predstavljala jednu od temeljnih preokupacija." (Šprah 2012, 194). Preuzimajući naslov drugog od svoja dva jedina kratka igrana filma, Ljubljana je ljubljena iz 1965, u kome se dvoje mladih traže i nalaze u ljubljanskim parkovima Tivoli i Rožnik, Klopčič sažima glavne teme i prostore svog opusa - društvena ograničenja, ljubav i težnju ka slobodi. Lično i subjektivno viđenje kolektivne istorije Drugog svetskog rata zadobija ovde kako lokalni kolorit tako i značajnu simboličku ravan opšteg usuda junakâ i njihovog rodnog grada, zatečenih u datim istorijskim okolnostima.

Celovečernji film Ljubljana je voljena stupa u dijalog sa Klopčičevim antologijskim igranim delom Sedmina (1969), posvećenom mladosti, ratu i revoluciji. Sedmina koristi fragmentarnu dramaturgiju i skokovite rezove u priči o dvoje maturanata, čiju mladost rat i italijanska okupacija pretvaraju u surovo odrastanje. U sižeu Ljubljane nalazi se zaplet sličan ovom: mladić Oton, svojevrsni alter ego samog Klopčiča i glavni narator priče, u okupiranoj Ljubljani prilazi ilegalcima, dok mu je otac u zatvoru. Međutim, Ljubljana je voljena ne odiše onim istim revolucionarnim duhom kakav je bio prisutan u Sedmini. U formalnom smislu, ovo je film klasičnije naracije, više umirenih emocija i setne nostalgije, koji burna zbivanja sagledava na mnogo opštijem fonu ukupnog života.

Ljubljana je voljena predstavlja portret i hroniku jednog grada, koji prolazi kroz mnoga iskušenja u predratnom, ratnom i poratnom razdoblju Drugog svetskog rata. Zbivanje započinje prologom iz 1934, kada je u Marselju ubijen jugoslovenski kralj Aleksandar I Karađorđević. Poetski intonirani likovi beskućnika dobrog srca, že-

\footnotetext{
${ }^{2}$ Ukoliko nije drugačije naznačeno, Republika Slovenija je osnovna zemlja produkcije filma koji se navodi. U zagradi se navodi originalni naslov filma.
} 
ne sa drvenim kolicima i muškarca u kaputu, koga tumači Polde Bibič, stalni glumac ovog reditelja, sublimiraju mudrost starosedelaca i bogatu istoriju slovenačke prestonice. Duša grada oslikana je kroz sudbinu jedne obične porodice koja podnosi ratna stradanja. To je porodica mladog Otona, čiji su otac i majka žrtve okupacije, a čiji prijatelj biva uhapšen i ubijen u potresnoj sceni streljanja u zatvorskom dvorištu.

Matjaž Klopčič je u svojim delima ovaplotio niz snažnih ženskih likova, mahom ruralnih junakinja koje poseduju ogromnu vitalnost, ljubavnu strast i želju za životom, ali zbog provincijske inercije i društvenih pravila zapadaju u dekadenciju i, nakon uzleta u slobodu, završavaju tragično (među njima su svakako antologijske uloge Milene Zupančič u Cveću u jesen (1973), Udovištvu Karoline Žašler (1976), i dr. Upravo kroz ove junakinje Klopčič u svom testamentarnom delu slika i karakter i usud ,,voljene Ljubljane“. Plavokosa Marijana, u tumačenju zanosne Ive Krajnc, oličenje je nevinosti i volje za životom. Njeno ime, koje aludira na francusku Marijanu, alegorijski simbol slobode i pobede francuskog naroda, daje osnovnu simboliku filmu: $u$ liku zavedene i pokorene nevine devojke ogleda se gubitak slobodnog i srećnog života u okupiranom gradu. Ona se iskreno predaje svojoj, kako sama kaže, „zabranjenoj ljubavi“ sa italijanskim generalom-okupatorom. Na kraju, ona u toj vezi doživljava jedno suštinsko izdajstvo, odnosno susret sa banalnom realnošću podređenosti, koji čini kraj njenih devojačkih snova. Marijana se sveti svome ljubavniku i dobrovoljno pristaje na tragične posledice svoga čina.

Karakteristična za pad okupirane Ljubljane jeste i figura igračice i pevačice Anite - kurtizane u pozorišno ocrtanom lokalnom kabareu - koju igra izvanredna Nataša Barbara Gračner, diva Klopčičevih poznih ostvarenja. Ova muza italijanskih vojnika i zapovednika, ali i domaćih mladića, u svojoj ličnosti spaja umetnost, hrabrost, drskost i vitalitet sa elegijom usamljene „gospodarice noći“. Kao takva, ona predstavlja drugo lice i upečatljiv pandan liku mile i grešne Marijane, koju njen iskusni ljubavnik Italijan naziva „čudom, čudom u Ljubljani“. Prateći ženski lik je i Sonja, čiji je verenik mobilisan, a koja pokušava da prekine aferu sa starijim lokalnim rediteljem, kažnjavajući se hodom na kolenima oko spomenika, sve dok joj iz rana na nogama ne poteče krv. Slobodna, poročna ljubav kod ovih junakinja predstavlja izraz tragične težnje da prevaziđu okove njihovog ratom ometenog života. Sa zrelošću starog čoveka, kod koga strasti mladosti poprimaju duboko osećajni okvir sećanja i nostal- 
gije, Klopčič majstorski režira poetske scene, u kojima od glavnih junakinja - nesrećnih zavodnica - pravi vizuelne simbole, alegorije samog grada. Ako je Marijana nosilac submisivnosti i romantičnog predavanja sudbini, pevačica i kurtizana Anita je svojevrsna avangardna figura, koja donosi modernu ikonoklastičnost i pobunu. U slikarski komponovanim kadrovima sfumata i jakih kolora, sa uticajem slikarstva baroka i romantizma, prizori često dostižu neočekivanu klasičnu lepotu, potcrtavajući ljupkost junakinja, njihove duge kose i obnaženog tela (direktor fotografije je čuveni Tomislav Pinter, koji je snimio više Klopčičevih filmova). Ovo delo odlikuje izuzetan klasičan stil pripovedanja sa bogatim vizuelnim rafinmanom $i$ stilizacijom prizora, sa naglašenim osećanjem za arhitekturu grada. Klopčič u Ljubljani ispoljava nepogrešivi osećaj za istorijsku epiku, koja se duboko prožima sa osećajnom melodramom. Nostalgični ton potvrđuje višestruka posveta filma - stogodišnjici slovenačke kinematografije, šezdesetogodišnjici oslobođenja Ljubljane, te uspomeni na slovenačkog pisca i političara Rudija Šeliga (1935-2004).

\section{„Balkan“ kao tema u slovenačkom filmu: Kajmak i marmelada (2003) i Južnjaci napolje (2013)}

Balkanski, odnosno bivšejugoslovenski sukobi i ratovi na kraju 20. veka još jednom su u brutalnom vidu iskazali postkolonijalne i istorijske tenzije ovog prostora. Politike identiteta, netolerancija i kriza multikulturalizma u današnjem svetu već dugo predstavljaju problem i na Balkanu, među čije zemlje se ubrajaju i sve bivše jugoslovenske republike i pokrajine (Slovenija se smatra zemljom na obodu Balkana, „najzapadnijom“ od svih južnoslovenskih država). Ideju „balkanizacije“, kao nečega „plemenskog, zaostalog, primitivnog i varvarskog“" (Todorova 1999, 15) artikulišu i teoretičari globalnog ekrana i hiperfilma - Lipovecki i Seroa: „(...) Na međunarodnom nivou, etnički i etnonacionalistički sukobi raspiruju se do jednog potpuno novog stepena. Trijumf neoliberalne globalizacije, povlačenje države i nestanak komunističkog carstva doneli su sa sobom umnožavanje nacionalnih cepanja, jedan uspon identitetskih, religioznih i terorističkih fanatizama, nove genocide i nove civilne ratove, totalitarne tribalizme koji naveliko i naširoko krše principe ljudskih prava. Vraćanje na etnoreligiozne identitete je otvorilo put za balkanizaciju konflikata ${ }^{3}$ (...). Posle obećanja srećnih demokratija koja su se pojavila u rasparčavanju Sovjetskog Saveza, došle su

\footnotetext{
${ }^{3}$ Istakla I. K.
} 
krvave anarhije nacionalnog identiteta, ratovi za redefinisanje granica, (...) gde su se međusobno ubijali, na ruinama stare Jugoslavije, Srbi, Bosanci i Hrvati“ (Lipovecki, Seroa 2013, 220).

Sa druge strane, stereotipi o Balkanu podrazumevaju i niz pozitivnih i željenih predstava o egzotičnom, orijentalnom, prisnom i duboko ljudskom. Pitajući se da li su zemlje Balkana ikada funkcionisale kao jasno definisan kulturni prostor, istaknuta istoričarka balkanskog filma Dina Jordanova ističe da svako bliže ispitivanje njegovih kulturnih i umetničkih sadržaja otkriva jednu „neverovatnu tematsku i stilsku utemeljenost. Naročito filmska umetnost svedoči o njegovom specifičnom umetničkom senzibilitetu, koji verovatno dolazi od zajedničkog istorijskog iskustva i socio-kulturnog okvira" (Iordanova 2006, 1). Ona, međutim, ističe kao problem činjenicu da balkanski film devedesetih godina nekritično prihvata evropocentričnu konstrukciju Balkana, čime se održava „paradoksalno pozicioniranje Balkana kao geografski priznatog dela Evrope, ali idejno isključenog iz evropskog kulturnog prostora" (Iordanova 2001, 56). Kao odgovor na ovu tendenciju, autentična kultura, muzika i duhovno nasleđe balkanskih naroda danas, u postkonfliktnom periodu, postaju značajan predmet savremenih studija kulture i umetnosti, te ravnopravni deo globalne popularne kulture.

„Balkan“ kao tema u jugoslovenskom, postjugoslovenskom i svetskom filmu, koju su pored ostalih proslavili i (eks)jugoslovenski reditelji Emir Kusturica i Milče Mančevski, kreće se od istorijskog epa ili epske fantastike, preko političke kritike / satire i porodično-političke drame, do vitalističke i snolike komedije i farse. Nevena Daković shvata Balkan kao slike-i-tekst-o-naciji i kao čitav filmski žanr, „žanr umetnosti, medija i kulture“ (Daković 2008, 11). „Balkan postaje vidljiv zahvaljujući bavljenju regionalnim temama socijalnih promena, kriza, upisa identiteta problematizovanih u evropskom kontekstu. U tom trenutku istorija balkanskog filma (...) postaje dominantno određena funkcionalnom vezom sa nacionalno-socijalnim i istorijskim formacijama i zbivanjima" (Daković 2008, 17).

S tim u skladu, savremene socijalne drame o doseljenicima s juga, po pravilu iz $\mathrm{BiH}$, povezuju realistični dramski narativ sa analizom problema i kritičnih tačaka koje otežavaju koheziju slovenačkog društva. Radi se, dakako, o filmskim narativima, koji zapravo svedoče o otvorenosti slovenačke kulture za razumevanje i prihvatanje društvenih protivrečnosti i različitosti, na šta ukazuje preispitivanje teme netolerancije $\mathrm{u}$ ovim filmovima. 
Ove, za datu kinematografiju veoma vitalne i učestale drame, $u$ istoriji slovenačkog filma imaju najmanje dva važna prethodnika do dvehiljaditih godina: Istim putem se ne vraćaj (Po isti poti se ne vračaj, c/b, SFRJ 1965), ${ }^{4}$ Joža Babiča (1917-1996), po scenariju Branka Pleše, i Autsajder (Outsider, 1997), scenariste i režisera Andreja Košaka. Babičev opori, naturalistički realizam drame o stanovnicima sa sela iz siromašne Bosne i Hercegovine, koji usled socijalne bede odlaze na rad u Sloveniju, u užasnim uslovima, jedan je od prvih jugoslovenskih filmova koji se dotakao tabu teme međuetničkih odnosa i netrpeljivosti u poratnoj Jugoslaviji. U filmu se ističe sugestivna gluma veoma moralnog junaka-nadničara, u tumačenju proslavljenog jugoslovenskog i srpskog glumca, kasnije i režisera, Ljubiše Samardžića (1936-2017).

Košakov Autsajder, izuzetno uspešan kod publike i lepo prihvaćen kod kritike, pomera ovaj društveni problem u dubinu, ka složenosti odrastanja i krize identiteta, te „kroz prizmu arhetipskog konflikta pojedinca i društva, intimnosti i javnosti, mladalačkog buntovništva i malograđanskog konformizma, ubedljivo rekonstruiše jedno sasvim određeno vreme“ (Trušnovec 2002, 13). Likovi i priča o ljubavi između mladića iz Bosne i devojke iz Slovenije, koji sticajem okolnosti pohađaju isti razred u srednjoj školi u godini Titove smrti, vođeni su veoma znalački i žanrovski uverljivo, sa autentičnim saosećanjem sa problemima mladih i sa duboko humanom kritikom represije unutar porodice i škole prema dobroćudnom mladiću, neshvaćenom od strane oca (Zijah Sokolović), rigidnog vojnog lica jugoslovenske armije, sa duboko birokratizovanom svešću, kao i prema svoj emotivno zapostavljenoj mladeži. Devojka je, međutim, usled malograđanskog „elitizma“ roditelja prisiljena da napusti mladog Bosanca. U glavnoj ulozi Seada briljira neposredni i duboko osećajni Davor Janjić, praćen čvrstom igrom Uroša Potočnika kao sadruga-pankera i Nine Ivanič kao građanski odgojene Metke. Nesvakidašnji kraj filma povezuje simboličnu kritiku autoritarizma i hrišćanski humanizam: dok sirene označavaju smrt predsednika Jugoslavije Josipa Broza Tita i „zamrzavaju“ sve aktivnosti i pokrete osoblja bolnice i ukupnog stanovništva, mlada Slovenka beži iz bolnice sa zakazanog abortusa i trči niz prazne ulice, ka slobodi. Njen verenik Sead izvršio je samoubistvo, ali dete njihove ljubavi preživljava, uprkos svim klasnim preprekama i kulturnom šovinizmu.

\footnotetext{
${ }^{4}$ Restaurirana verzija ovog filma prikazana je na otvaranju Dana slovenačkog filma u Beogradu 2017. Videti: https://www.danislovenackogfilma.org/
} 
Balkan kao tema i „kulturna drugost“ manje razvijenih sredina unutar Balkana i druge Jugoslavije pokazuje se za slovenački film kao vitalna građa za iskazivanje kritičkog senzibiliteta spram društvene i klasne krutosti, i potencijalnog kulturnog rasizma i fašizma. Neodoljivi doprinos ovoj tematici dao je svestrani muzičar, komičar i reditelj Branko Đurić Đuro, nekadašnji član kultne sarajevske dramske grupe „Top lista nadrealista“, u svojoj nadahnutoj melodramskoj komediji Kajmak i marmelada (Kajmak in marmelada, 2003), koja se bavi vezom dvoje odraslih ljudi, Bosanca Bože (Branko Đurić Đuro) i Slovenke Špele (Tanja Ribič). Ovo dvoje glumaca su bračni par i u realnom životu. Dva nacionalna jela koja se tradicionalno spravljaju u kućnoj radinosti, nespojivo drugačijeg „karaktera“ i ukusa, dala su duhoviti naslov ovom ostvarenju. Izvanredna stilizacija situacija i ponašanja glavnog junaka uključuje i vožnju biciklom, koji pak figurira kao njegov lični znak jedne putujuće i „neobavezne“, u suštini nesigurne egzistencije, a na koji se Božo oslanja kao Šarlo skitnica na svoj štap. Božo gubi i bicikl, koji mu ukradu, ostajući tako prepušten „na milost i nemilost“ uličnom imigrantskom opstanku. Tatijevska komika i pantomima, te detinja naivnost junaka, izdvajaju Đurića - alijas Božu - kao mitsku figuru nesnađenog, toplog Balkanca, zarobljenog u tragičnim / tragikomičnim uslovima sopstvene egzistencije.

Koristeći sigurni okvir komične melodrame, Đurić neodoljivo postavlja osnovni dramski sukob u okvir kulturološke „drugosti“ bosanskog i slovenačkog senzibiliteta, ističući pritom razliku u zrelosti između uspavanog i nezaposlenog šarmantnog deteta-u-telumuškarca i njegove odsečne i rešene supruge, koja želi potomstvo. Kako bi udovoljio ženi koju voli, te ponovo zadobio njenu naklonost, Božo se upušta u jedinu socijalnu mrežu koja mu je dostupna: u mutne muške poslove sa južnjačkom, „zemljačkom“ emigracijom, na čelu sa Goranom (Dragan Bjelogrlić). Dati poslovi uključuju kriminal i reketiranje praćeno tučom, koje se, obrtom sudbine, događa upravo u „finom“ domaćem restoranu, u koji je Špela izašla sa svojom porodicom i prijateljima. Junak Božo biva ranjen i tako spašava čast, ali ne i zdravlje. Na kraju filma, nakon optimistične scene $u$ kojoj Špela i Božo zajedno izvode dete u park, priča se ipak završava u neizbežnosti razmimoilaženja dva sveta: sveta „evropske beline“ slovenačke kulture i visokog standarda i sveta „Balkanaca“, došljaka, izloženih diskretnoj, ali hroničnoj i uhodanoj diskriminaciji. Oni ostaju izolovani u sopstvenim obrascima mačo-kulture, sive ekonomije i nesreće $u$ neuklopljenosti u društvo. Neodoljivi duh čežnje 
za porodičnom srećom, koja je kako ometena tako i isprepletena sa individualnim razvojem junaka / junakinje, a kakav je dosegao Đurić $\mathrm{u}$ ovom sjajnom ostvarenju, na najbolji način je ponovo pronađen $\mathrm{u}$ lucidnoj, scenaristički i žanrovski briljantnoj, komičnoj porodičnoj drami iz ženskog ugla Barbare Zemljič - Panika (2013).

Inspirisan netrpeljivim uličnim grafitom sadržaja „Čefurji Raus!“, što znači „Južnjaci, napolje!“, istoimeni roman Gorana Vojnovića iz 2008. godine poslužio je mladom piscu kao predložak za sopstveni dugometražni igrani film istog naslova, u kome potpisuje scenario i režiju. Roman Čefurji Raus! nagrađen je 2009. godine prestižnim nagradama Prešernovog sklada i časopisa Delo za najbolji roman protekle godine. Sa velikim uspehom izvodi se i kao monokomedija u teatru. Goran Vojnović je do sada autor tri uspešna romana, među kojima su i Jugoslavija, moja dežela (Jugoslavija, moja zemlja ${ }^{5}$ ) iz 2012, koja se takođe igra i u pozorištu, i Figa (Šipak) iz 2016. Uspeh i popularnost Vojnovićevih književnih dela pokazuje veliku aktuelnost osetljivih tema raspada Jugoslavije i međunacionalnih socijalnih netrpeljivosti, ali i veštinu autora da date teme obradi sa optimizmom i humorom, te razobliči predrasude koje oštećuju život ljudi. Na sličnu temu je ovaj autor napisao i režirao kratki film Fužine zakon (2002).

Film Južnjaci, napolje! snimljen je 2013. godine. Radi se o omladinskoj socijalnoj drami, koja prati mladog junaka Marka (Benjamin Krnetić), koji, kao i u romanu, pred gledaoce iznosi svoj unutarnji monolog. Marko i njegovi drugovi i drugarice odrastaju u situaciji prigušenih socijalnih tenzija između „došljaka“ u Sloveniju nakon raspada SFRJ, koji su poreklom iz Bosne, i domaćeg stanovništva koje ih ne prihvata u potpunosti. Daleko moderniji u izboru teme i režijskom postupku, koji je pod uticajem kulture mladalačke pobune i muzičkog videa, ovaj film je bitno drukčiji od Vojnovićeve prilično klasične ratne melodrame Piran - Pirano (2010), ${ }^{6}$ koja grupu junaka iz Pirana prati tokom istorije 20. veka, uključujući potresna zbivanja u Drugom svetskom ratu.

Mladalačka uzbuđenja i nade mladića i devojaka iz ljubljanskog predgrađa Fužine obeležena su tako teretom prošlosti i ratnih i političkih trauma, te osećanjem obeležnosti i izopštenosti iz društva.

\footnotetext{
${ }^{5}$ Kod naziva romana u zagradi je naveden prevod naslova na srpski jezik.

${ }^{6}$ Kao jedinstvena lokacija sa bogatom istorijom i arhitekturom, primorski gradić Piran bio je mnogo puta mesto radnje i područje snimanja atraktivnih slovenačkih filmova i koprodukcija. Videti detaljnije u: Širca Majda Piran v filmu: koprodukcijski časi Slovenije. Obalne galerije, Piran, 2014.
} 
Omladina oseća otpor prema tome da pripada implicitno inferiornoj kulturnoj manjini u bogatijoj Sloveniji. Deo mladića živi u disfunkcionalnim porodicama, sa odsutnim ili pijanim očevima i nesretnim majkama, čiju brigu i žrtvu odbacuju. Kompleks niže vrednosti meša se kod naših junaka sa nabojem erotskih želja i agresije, te se iskazuje u ritualima alternativnog i izgredničkog ponašanja i grubog dobacivanja devojkama. Njihovi nestašluci prerašće i u sukob sa policijom, koja ih nakon incidenta $u$ autobusu privodi na brutalno noćno saslušanje.

Film je režiran u čvrstom i oporom realističnom stilu, što je netipično za slovenački filmski izraz, koji po pravilu naginje melodrami i vizuelnoj simbolici. Vojnović gradi izvestan otklon od realizma kroz elemente komedije i satire, te kroz izmaštane scene priviđenja, ali prevashodno ostaje veran socijalnoj uverljivosti i dokumentarizmu. Ističe se iskusan glumački ansambl sa prostora bivše Jugoslavije - od Emira Hadžihafisbegovića, Meta Jovanovskog, Mustafe Nadarevića i Jerneja Šugmana do Medihe Musliović, Vesne Trivalić i Polone Juh, kao i sveža i prirodna igra mladih glumaca i naturščika.

Uvodna scena porodične slave je naročito prisno i realistično dočarana, sa osećajem za modernu etnologiju i običaje srpske i makedonske manjine u Sloveniji. Uz prepoznatljivu muziku i ishranu, data je i ikonografija tipičnog stana pripadnika srednjeg sloja u bivšoj Jugoslaviji. Komšija Slovenac još na početku filma odbija da uđe na Slavu, čime se ukazuje na već prisutna razdvajanja i buduće tenzije. Dijalozi junaka koji potiču iz istog naroda i porodica često se odvijaju dvojezično - na slovenačkom i srpsko-hrvatsko-bošnjačkom, što podvlači njihovu duševnu i kulturnu podvojenost.

Scena utakmice nadalje ukazuje na uporedne procese razdvojenosti i, sa druge strane, mogućeg uklapanja „stranaca“ u slovenačko društvo, sa svađama između mladih igrača, koje u podtekstu imaju etničko ponižavanje i napetost. Sledi scena sa policijom, u kojoj mladići, nakon davanja svojih srpskih i bošnjačkih imena, stupaju u uzajamne provokacije sa policajcima, da bi potom bili ubačeni u tzv. maricu. Reakcija policije može se tumačiti kao ukupni stav društva u kome se odvija radnja - ona sadrži pomešanu brigu i omalovažavanje. Policija momke malo zaplaši, ali ih izbaci u šumi i pusti ih da idu kući. Ove duge grupne scene date su kao inicijalne socijalne situacije, iz kojih se kasnije grana ulično „gluvarenje“ omladine ispred „bloka“, koje se kreće ka sumnjivom ponašanju, a koje je prikazano u drugom delu filma. Iživljavanje u ludoj vožnji kolima, uz „narodnjake“ koji nerviraju prolaznike, deo je zabave mladića kojom 


\section{\begin{tabular}{|l} 
I. Kronja \\
Neke autorske tendencije u ...
\end{tabular}}

stiču kratki osećaj superiornosti. Njihovo nezadovoljstvo kulminira u osvetničkom prebijanju starog vozača autobusa i namerno izazvanom požaru ispred solitera.

U srcu dramaturgije filma nalazi se, za omladinske filmove tipičan, sukob oca i sina. Oni pripadaju različitim generacijama i odlikuju ih nepomirljivo suprotstavljeni vrednosni sistemi i muški identiteti. Otac Radovan, u izvanrednom, veoma srčanom tumačenju Emira Hadžihafisbegovića, tipičan je predstavnik klasičnog muškog identiteta i eksjugoslovenske radničke klase. Njegov sistem vrednosti temelji se na radu, poštenju i skromnosti, te na odanosti porodičnom životu. Sin Marko je sportista, košarkaš, koji ne želi to da bude. Njega odlikuje kriza smisla i identiteta, tako karakteristična za današnju mladu generaciju. Ovaj junak je nosilac sindroma „buntovnika bez razloga“, jednog rascepljenog modernog čoveka. Majka Ranka, koju igra Mediha Musliović, pasivna je žena, koja obavlja kućne poslove i smiruje porodične tenzije. Ona se sa puno sentimenta zalaže da Marko popravi svoj slab uspeh u školi. I otac i majka svoje nade za bolju budućnost polažu u sina Marka i njegovu profesionalnu sportsku karijeru, računajući na njegove fizičke predispozicije i talenat. Međutim, unutarnje psihološke tenzije i porodični pritisak čine da mladić odbija ovu uspešnu projekciju života. On se, naprotiv, identifikuje sa mangupskom omladinom iz kraja, te sa starijim muškarcima iz polukriminalnog andergraund miljea, koji žive u emigraciji i povremeno dolaze u njihovo naselje. Devojka iz susedstva, koja radi na televiziji, pokazuje se za rastrzanog mladića kao banalni, ali nedostižni objekat želje i snova o društvenom uspehu. U dirljivoj sceni porodičnog razgovora, Marko pokušava da objasni ocu svoje emocije koje su ga navele na loše postupke, ali ne nailazi na pravi odgovor, niti pak na očevo razumevanje.

Doživljavajući sebe kao otpadnika, u pobuni protiv klasno i etnički podeljenog društva, Marko odbija da ispuni očeve snove, te puši, tuče se i, konačno, prestaje da trenira. U neočekivanoj završnici, otac odlučuje da poštuje njegov izbor, ali tako što će ga vratiti u siromašni kraj iz koga su potekli. Čefur, stranac, sada postaje Janez, što je pogrdno ime za Slovenca. Muzika grupa Kultur šok i Dubioza kolektiv, te Eda Majke, Iztoka Turka i Manjifika u tehno-hard-kor stilu, daje čvrst ton poruci omladinske pobune u ostvarenju Južnjaci, napolje!. 
Autorske poetike i „Socijalni horror“: Anžlovar, Kozole, Cvitkovič, Möderndorfer

Pojam „socijalnog horora “7"odnosi se na društveno angažovane filmove, koji radikalizuju situacije društvene nepravde, nasilja i političke korupcije, kako bi jasnije ukazali na njihovu strukturu i uzroke. U ovom postupku, „socijalni horror“ se služi vizuelno ekspresionističkim i naturalističkim pristupom u stilu i ikonografiji, i u prikazu nasilja prema telu, obično gradacijski, postižući efekat neizdržljivosti opisanih situacija za aktere i gledaoce kako dramskim tako i audio-vizuelnim stilskim sredstvima, neretko bliskim horor-žanru. Estetizacija nasilja u ovoj vrsti filma ne služi, kao što je to slučaj u mejnstrim produkciji, učinku zabave i normalizacije, već, suprotno tome, mobilizaciji gledalaca protiv užasnih i nepravednih pojava u konkretnom društvu i globalno.

Vinci Voug Anžlovar (Bakica ide na jug, Vampir z Gorjancev) je autor scenarija, režije i scenografije $u$ akcionoj igranoj drami Poker iz 2001. godine. Ovo ostvarenje započinje kao dokumentarna rekonstrukcija zbivanja $\mathrm{u}$ životu jednog okorelog, profesionalnog kockara, da bi preraslo u svojevrsni filozofski esej o psihopatskom umu. Kulminacija filma predstavlja uzbudljivi prikaz prave pandemije zločina i nasilja, koja ne ostavlja nikog živog iza sebe, a kakva je retko viđena $u$ savremenom eksjugoslovenskom filmu; $u$ našem regionu, kao najbliže ovoj poetici bespoštedne surovosti pokazuju se srpske kriminalističke akcione drame Do koske (1997), Bobana Skerlića, i Rane (1998), Srđana Dragojevića.

Poker se sastoji iz nekoliko ključnih sekvenci, koje funkcionišu kao zaokružene dramske celine, smeštene $\mathrm{u}$ jednom istom prostoru. Više junaka ima svoje duge ispovedne monologe, u kojima objašnjava svoj poziv, svoj svetonazor, te svoju motivaciju za zločine. Tema profesionalnog kockarskog zanata u ovoj filmskoj priči neraskidivo je vezana sa mafijaškim delovanjem i sadističkim nasiljem, koje kulminira na kraju neuspelog kockarskog takmičenja u pokeru, planiranog i započetog na tajnoj lokaciji, na koju stižu oba glavna junaka. Može se reći da sekvenca dugog i mučnog kockarskog meča, koji prerasta u bizarni krvavi obračun, biva centralna u filmskoj priči i da nosi čitavu drugu polovinu filma.

\footnotetext{
${ }^{7}$ Neki od primera savremenog „socijalnog horora“ su, po nama, ruski film Budala (2014), Jurija Bikova, američki Rvač (2008), Darena Aronovskog, srpski filmovi Život $i$ smrt porno-bande (2009), Mladena Đorđevića, i Srpski film (2010), Srđana Spasojevića, kao i niz drugih ostvarenja.
} 
Film Poker posebno treba pogledati zbog fascinantnog početka, u toku kojeg nismo sasvim sigurni da li se radi o dokumentarnom ili o igranom filmu. U tehnici saspensa, koristeći crno-belu fotografiju, reditelj nas izlaže direktnoj ispovesti profesionalnog kockara Pavla, koga tumači sigurni i harizmatični Pavle Ravnohrib. Iskusni junak sugestivno komentariše svoju profesiju i iznosi svoju filozofiju kocke kao „tajnog znanja“. Njegov monolog, međutim, započinje jednom tipičnom filmofilskom referencom, opisom Belmondove scene iz antologijskog filma Do poslednjeg daha (1960), Žan-Lik Godara, u kojoj junak izgovara: „Da, veoma je lepo na selu“. U ironičnom duhu, Pavle svoje životno opredeljenje pozicionira sasvim suprotno od mirnog seoskog života. On vidi kocku kao područje zadovoljstva, inteligencije, samoostvarenja i rizika. Docnije će u filmu Poker junaci ponovo razgovarati o ovom kultnom Godarovom prvencu, nosiocu ideje apsurda i anarhične slobode, oličene u stilu života i pogibiji glavnog junaka tog filma - Mišela (Jean-Paul Belmondo). Bogatstvo scenarističkog dijaloškog teksta koje odlikuje Poker posebno je prisutno u ovoj prvoj sceni. Junak Pavle iznosi čitavu filozofiju kocke kao vrhunske igre, analizirajući poreklo predrasuda o njenom „demonskom“ poreklu. Kada bi čovek u potpunosti ovladao kockom i otkrio tajnu promenljive vrednosti, on bi time postao bliži i samom Bogu, cinično zaključuje ovaj junak.

Kockar Pavle predočava gledaocu čitavu metodologiju sticanja bogatstva na kocki, objašnjavajući kako on sam igra za druge ljude koji ulažu novac. Rizik posla snosi ulagač, a ako igrač pobedi, što je najčešce slučaj, prihod se deli u dogovorenom procentu, u kome glavnu zaradu, dakako, stiče ulagač. Navedeni moralno kontroverzni detalji, kao i elementi meča u drugom delu filmske priče, mogu biti posebno interesantni za gledaoce koji i sami uživaju u igranju pokera, ili pak nameravaju da se ovoj igri posvete.

Dalji nastavak priče prati junaka Boruta, u tumačenju slovenačkoj publici dobro poznatog glumca Boruta Veselka, koji likom veoma podseća na pop-rok pevača Bili Ajdola. Filmska slika sada prelazi $\mathrm{u}$ puni kolor. Junak nosi frustraciju od raskida s devojkom, koja ga je očigledno napustila zbog verbalno nasilničkih ispada, koje i sami vidimo. Iako poprilično kameran i monoton, sa premalo detalja, ovaj deo filma daje izvanrednu analizu psihologije psihopatske ličnosti, kakva je Borut. On ne pokazuje nikakvu milost niti za dečaka koga je zgazio na putu i potom hladnokrvno bacio u kontejner, niti za Pavla kome se $\mathrm{u}$ nedođiji pokvario auto. Borut prima Pavla kao auto-stopera u svoj automobil. Njih dvojica povremeno 
vode veoma inspirativne, ontološki intonirane rasprave o ljubavi i smislu života, koje prerastaju u teško uzajamno vređanje i uvredu njihovih dojučerašnjih životnih saputnica. Kao takoreći antologijska, izdvaja se diskusija o ukusu kafe, koja prelazi u verbalno neprijateljstvo između Boruta, kao poklonika čistog ukusa kafe bez šećera i mleka, i Pavla, koji takvu kafu ne podnosi. Borutov odnos prema Pavlu, koji sa sobom nosi veliki novac za takmičenje u pokeru, prerasta $u$ teško iživljavanje, sa bizarnim detaljima otkopavanja stare lobanje, kao u Hamletu, te uživanja u psihičkom mučenju i pokušaju ubistva Pavla.

Borut nakon toga stiže na mesto ilegalne partije pokera - $u$ podrum, gde se susreće sa ostalim igračima sumnjivog morala i emotivnog statusa, kao i sa lepom asistentkinjom koja deli karte - Vesnom (Urša Božič). Dvojica igrača primećuju da on igra sa obeleženim novcem, te obaveštavaju o tome svoga potuljenog šefa. U efektnoj epizodi u kojoj igra šefa mafijaša i ubicu, vidimo Branka ĐurićaĐuru. Na poprište zbivanja stiže i teško ranjeni Pavle, koji je preživeo Borutova iživljavanja.

Poslednji deo filma predstavlja pravu orgiju nasilja, koje se odvija prema zakonima apsurda: netrpeljivost, mržnja, osveta i niske strasti čine da broj žrtava raste do same završnice. Etična poenta filma je da nijedan izvršilac mučkog ubistva ne ostaje nekažnjen. U ovome se Anžlovarovo ostvarenje razlikuje od svojih očiglednih uzora, kao što su filmovi Kventina Tarantina, Majkla Beja, Roberta Rodrigeza, i drugih. U Pokeru, on nasilje posmatra filozofski, dovodeći ga do apstraktnog principa, ostajući u ovoj stilizaciji, na kraju svega, odgovorni kritičar negativnih pojava u društvu.

Reditelj i scenarista Damjan Kozole ističe se kao veoma plodan autor, dosledan svome stavu i poetici podjednako u kratkom, dokumentarnom filmu, kao i u celovečernjem, igranom filmu. Dobitnik je nagrade za životno delo na Filmskom festivalu u Rimu 2012. Najličniji Kozole, po nama, biva u dramama koje dosežu nivo ontološke rasprave o pitanjima istine, dobra i zla, kakva je analitična psihološka studija porodičnog nasilja i neverstva, urađena u skučenim, ali duboko promišljenim uslovima kamernog filma Zauvek (Za vedno, 2008), te u nesvakidašnjoj samosvesnoj parodiji na filmske konvencije i žanrove - Stereotip (1997). Izvanredne vivisekcije lokalnog društva i socijalnih struktura, posebno klasnih privilegija i korupcije, povezanih sa ličnim nasiljem ili stradanjem i dubokim otuđenjem junakinja i junaka, ponudio je Kozole $u$ atraktivnim produkcijama žanra trilera / neonoara i tona „moralnog 


\section{Kronja \\ Neke autorske tendencije $\mathrm{u} . .$.}

nespokojstva“ (odjek novotalasnog evropskog i američkog autorskog filma) - Porno film (2000), Slovenka (2009) i Noćni život (Noćno življenje, 2016), za koji je osvojio nagradu za najbolju režiju u Karlovim Varima 2016.

Uzbudljivi socijalni krimić Rezervni delovi (Rezervni deli, 2003) odlikuju dokumentaristički naturalizam u stilu, besprekorna napetost i ozbiljna gorčina u susretu sa ljudskim gresima - bezdušnošću, pohlepom i nasiljem. Film govori o tome kako su „savremeni balkanski putevi trgovine drogom i ljudima doveli na Balkan imigrante Trećeg sveta u prolazu ka Zapadu“, bivšem Sovjetskom Savezu i Bliskom istoku (Daković 2008, 53). Rezervni delovi sadrže i opominjuću satiru prema mačizmu, oličenom u nekadašnjem vozaču moto-trka i okorelom šverceru ljudima - Ludviku (Peter Musevski), koju prate i trunke nostalgije za „starom Jugom“. Odvratni akteri ne mogu zamisliti odnos sa ženama bez ponižavanja i ucene glađu i zdravljem, odnosno životom, bez obzira na to da li su ovi odnosi dati na sofisticiranijem nivou, kao u Slovenki ${ }^{8}$, ili u ogoljenoj situaciji preživljavanja, kao u Rezervnim delovima. U jednoj od scena, romantična pesma o ljubavi - Cesarica, u interpretaciji eks-ju kantautora Olivera Dragojevića (1947-2018), čuje se tokom susreta mladića Rudija (Aljoša Kovačič) i ostavljene devojke Angele (Aleksandra Balzamović) u nužniku, čime reditelj postiže rečiti komentar o niskoj, „paloj“ prirodi muško-ženskih odnosa u datom miljeu (ili uopšte). Ovde nostalgija prerasta u društvenu kritiku nepromenljivo surovih odnosa. U Rezervnim delovima, ubistvo sa komadanjem ljudskog tela na organe radi ostvarivanja profita proglašava se ekonomskom nuždom u „objektivnim uslovima“ i istovremeno figurira kao metafora nepovratne tranzicije i kraja utopije socijalizma ${ }^{9} \mathrm{i}$ humanog društva. Kao najzanimljivija figura izdvaja se upravo uloga mladog Rudija, švercera ljudi, koja stoji na „prelazu“ između „dobrih" i „loših“, žrtava i počinilaca. On odbija da do kraja ponižava žrtve, ali zapravo celovito učestvuje u zločinu koji se odvija, takoreći, „sam od sebe“. Ova vrsta političkog konformizma i pristanka na nedela tekućih režima u globalnom kapitalizmu, karakteristična za

\footnotetext{
${ }^{8}$ Radnja filma prati mladu studentkinju koja se upušta u zarađivanje radeći kao poslovna pratnja, da bi jednom prilikom visoki službenik evropske administracije preminuo tokom susreta sa njom $u$ hotelskoj sobi.

${ }^{9}$ Početak filma donosi dokumentarne snimke otvaranja nuklearke Krško od strane tadašnjeg predsednika SFRJ, Josipa Broza Tita, kao zaloga bolje budućnosti; ovo postrojenje nadalje u filmu figurira kao mesto ilegalnog graničnog prelaza za imigrante i žrtve trgovine ljudima.
} 
ogromnu većinu ,građana“ i ,,građanki“, ingeniozno je predstavljena ponašanjem datog lika u Rezervnim delovima.

Izraziti primer nezavisne autorske poetike i socijalne kritike $\mathrm{u}$ slovenačkom filmu predstavlja harizmatični glumac, scenarista i reditelj Jan Cvitkovič. Upečatljivom pojavom i glumačkim nastupom u spoju apsurda i nevinosti, $u$ antologijskom igranom prvencu Janeza Burgera - U leru (V leru, 1999), crno-belom ostvarenju andergraund estetike i džarmušovskog duha i jednom od najvažnijih slovenačkih filmova iz devedesetih, ${ }^{10}$ Cvitkovič, kao večiti student Dizi sa stalnim boravištem u studentskom domu, postao je praktično koautor dela. Prema Meti Mazaj, ,,precizno konstruisana kompozicija prostora u ovom filmu nema samo narativnu funkciju, već i sinematički dočarava sliku Slovenije kao problematičnog mesta tranzicije, prelaska” (Mazaj 2011, 13). U leru, prema ovoj autorki, koncentriše u sebi upravo dominantnu crtu novog slovenačkog filma, u kome „tranziciona realnost (koja se uvek uzima zdravo za gotovo $\mathrm{u}$ političkom diskursu), sada ponovo promišljena $\mathrm{u}$ terminima socijalnog prostora, postaje problematična, dok se proces preoblikovanja nacionalnog prostora pokazuje kao neuspešan. (...) Najveći deo filmova ovog Novog (slovenačkog) talasa daje oštru kritiku tranzicione stvarnosti koristeći temu marginalnosti i otvoreno pokazujući očaj skriven pod sjajnim ali beskrupuloznim licem nesputanog kapitalizma“, dajući sliku „ne uspeha već tihe dekadencije“ (Mazaj 2011, 11-12).

Tranzicija i osećaj za marginalnost doneli su, međutim, i poseban kvalitet slovenačkom autorskom i art-filmu, kakvi su Cvitkovičevi Hleb i mleko (Kruh in mleko, 2001) i Od groba do groba (Od groba do groba, 2005), u kojima nadahnuto i naturalistično igra istaknuta jugoslovenska i srpska glumica Sonja Savić (1961-2008). Ovi izrazito estetični i hermetični filmovi malog budžeta konstruišu jedan viši nivo poetske realnosti i metaforiku osnovnih ljudskih i etičkih pitanja, uključujući religiju i patnju tela i duše. Zdravu protivtežu ovim ostvarenjima u Cvitkovičevom opusu gradi urnebesna treš-komedija Šiška deluks (Šiška Deluxe, 2015), kritika od strane sistema proizvedenog siromaštva i promocija igre i međuljudske solidarnosti.

Cvitkovičeva socijalna drama Osnove ubijanja (Družinica, 2017) koncentriše više deprimirajućih iskustava lokalnog neoliberalnog kapitalizma u jednu porodičnu priču. Atraktivna Dunja, uprkos izvanrednim istraživačkim rezultatima, biva otpuštena s posla:

${ }^{10}$ Film je otvorio slovenački „novi talas“ nakon secesije od SFRJ / SRJ i bio je višestruko prikazivan i nagrađen $\mathrm{u}$ inostranstvu. 
odeljenje za razvoj se ukida, a ona odbija šefova udvaranja. Profesor književnosti Marko nevino je optužen za napastvovanje učenice, koja mu, u sopstvenoj medijski indukovanoj tinejdžerskoj erotizaciji i narcizmu, priređuje dvosmislenu scenu na kraju časa. Od njega se zahteva da dâ otkaz. Njihova deca i oni sami, nekada dobrostojeći građanski sloj, postepeno ostaju bez hrane, bivaju društveno odbačeni, a otac zapada u alkoholizam. Posebno su lucidni momenti u kojima pijani Marko u kafani drži predavanja o Sokratu i Platonu, časti i državi. Materijalna degradacija donosi i moralnu, sve dok u stanu ispražnjenom od strane kreditnih poverenika, uz sveće i ostatke pice, porodica ponovo ne pronađe ono nematerijalno - ljubav i solidarnost. Dramski vešto oblikovan, sa dugim, višemesečnim pripremama dece-glumaca i njihovih filmskih roditelja, ovaj film visoke produkcije oslanja se na fizičku prisutnost i emocionalnu harizmu neposredne Irene Kovačević kao Dunje i sugestivnog i srčanog PrimožaVrhoveca kao Marka, uz nezaboravnu igru devojčice Ule Gulič.

Cvitkovičeve Osnove ubijanja predstavljaju, pre svega, jednu moralnu skasku, emotivnu i metaforičnu sliku društvenog raspada, koja se pokazuje blažom i optimističnijom od svog prethodnika na istu temu - izvanrednog socijalnog horora Inferno (2014), istaknutog slovenačkog književnika, scenariste, pozorišnog, radio i filmskog reditelja Vinka Mederndorfera (Vinko Möderndorfer). Film je bespoštedna analiza efekata neoliberalnog kapitalizma, u kome izostaje zaštita socijalne države, i njemu imanentne prljave privatizacije na pripadnike nekadašnje socijalističke radničke klase. Inferno koristi jezik vizuelnog prenaglašavanja stravičnih efekata sloma ličnosti, koji se opipljivo ogledaju u gradacijski sve gorem telesnom razaranju junaka-pravednika (izvanredni Marko Mandić), koji strada za nepriznatu istinu činjenice klasne eksploatacije do fizičke smrti. Vizuelna semantika horora i kasapljenja tela stavlja se ovde u funkciju socijalnog angažmana na strani povraćaja ljudskih prava, masovno oduzetih ljudima od strane novih moćnika.

\section{Žene autorke: Maja Vajs i Majda Širca}

Kao verovatno najemancipovanija $u$ pogledu ženskih prava $i$ rodne ravnopravnosti među zemljama poteklim iz bivše SFRJ, Slovenija je razvila i autorski prostor za filmske autorke, posebno $\mathrm{u}$ domenu dokumentarnog i kratkog, a povremeno i celovečernjeg igranog filma: Majdu Širca, Maju Vajs (Maja Weiss), Hanu Slak, Uršu Menart, Barbaru Zemljič, Sonju Prosenc. U susednoj kinematogra- 
fiji Hrvatske, pak, žensko filmsko stvaralaštvo ostvarilo je najveći domet u okvirima animiranog i eksperimentalnog (Ana Hušman, Petra Zlonoga), ponekad i kratkog i dugog igranog filma (Snježana Tribuson, Ivona Juka, Hana Jušić), dok se u Srbiji i Makedoniji nakon dvehiljadite posebno izdvojilo nekoliko autorki unutar nezavisnog i mejnstrim igranog filma (Jelena Marković, Maja Miloš, Tamara Drakulić, Teona Strugar Mitevska). Najveću stabilnost ženskom autorstvu, među eks-ju zemljama, pružila je kinematografija BiH (Jasmila Žbanić, Aida Begić). Dokumentarizam, sa mogućnošću nezavisne produkcije i manje filmske ekipe, pokazuje se kao sigurno pribežište i uspešan kreativni prostor za rediteljke u svim navedenim kinematografijama.

Svojim igranim prvencem Varuh Meje (Čuvar granice, 2002), priznata i antiratno angažovana dokumentaristkinja Maja Vajs (Cesta bratstva in enotnosti, 1999; Dar Fur - Vojna za vodo, 2008; Odkrivanje skritega spomina Angele Vode, 2011; Slovenskom narodu ukradena deca, 2014. i dr.) osvojila je značajne nagrade ${ }^{11}$ i uzburkala mnoge duhove, sumirajući zapravo glavne težnje savremenog slovenačkog autorskog filma na jedan nadasve samosvesni, „ženski“ način. Glavne junakinje filma, gonjene pre svega iracionalnom željom za celinom sopstvene ličnosti, upuštaju se u neizvesnu avanturu po šumama i brzacima negde u unutrašnjosti, tražeći simbolički prostor koji će biti „izvan“ patrijarhata. Tokom plovidbe čamcima junakinje će reći: „Ovo je super! Nema ni roditelja, ni profesora, ni tipova, nikog da gnjavi“. Susret sa prirodom, sa nedirnutim rečnim krajolikom i smenama sumraka i praskozorja, dana i noći, nudi mogućnost „spiranja“ nataloženih slojeva stečenog karaktera i povratka dubini svog bića, susreta sa sopstvenim osećanjima koja se kriju ispod društvene „maske“. Muškobanjasta fotografkinja Žana (Pia Zemljič), prkosna Alja (Tanja Potočnik) i, kao treća, poslušno ženstvena Simona (Iva Krajnc) počinju tako da govore o sebi, ne bez uzajamnog otpora ovim neprijatnim suočavanjima sa istinom i tajnama. U nizu scena koje grade izvanrednu snoliku poetsku celinu, Simona se susreće sa muškim simbolima i samom muškom figurom nepoznatog stranca, egzotičnog pecaroša, koja kao da dolazi iz njenih snova i podsvesti. Ispostaviće se da je on policajac koji hvata ilegalne useljenike, „čuvar granice“ (odatle i naslov filma), ali i oženjeni otac, kandidat za mesnog župana (Jonas Žnidaršič).

\footnotetext{
${ }^{11}$ Berlin FF 2002 - Nagrada Manfred Salzberger za najbolji evropski inovativni film; nominacija za Fazblinderovu nagradu za evropsko otkriće, koju dodeljuje Evropska filmska akademija. Izvor: https://www.film-center.si/sl/film-v-sloveniji/filmi/ oseba/4568/maja-weiss/.
} 


\section{Kronja \\ Neke autorske tendencije $u$...}

Gubeći svoje udobne maske, devojke nailaze i na nepredviđene teškoće i muško nasilje, na iskušenja koja moraju da prebrode. Kako ističe Pavičić, put u provinciju u postjugoslovenskim filmovima najčešće znači „otkrivanje“ istine / istorije i izlazak iz zone eskapističke udobnosti: tako u Varuh Meje / Čuvaru granice „bezazlene kajakašice otkrivaju u porečju Kupe realnost fašisoidne slovenačke provincije“ (Pavičić 2011, 104). Reka je na granici Slovenije i Hrvatske, viđene i dalje kao područje neprestanog rata. U jednom trenutku preći će je i izbeglice, koje će na licu mesta uhvatiti policija. Jedna od izbeglica je izgleda nestala i možda stradala, ostavivši narandžastu sandalu za sobom, u trenutku kada devojke polaze na put, što su javili i mediji.

Situacije kroz koje junakinje prolaze vođene su znalački rukom rediteljke po ivici psihološke jeze i fizičkog horora, koju ipak ne prelaze, prizivajući atmosferu i stihove Šekspirovog Sna letnje noći. Noćne scene, koje su impresivno snimljene, imaju mističnu i „zabranjenu" atmosferu, dok lokalno narodno slavlje odiše pretnjom uništenja devojaka-pridošlica. Film se kreće od hrišćanskih simbola - raspeće, riba - do paganskih uprizorenja - ubijena riba, vatra, noćni rituali. Dati simboli izraženi su u predstavljanju junakinja i junaka, narodnog kolektiva i prirode. Očinska figura pokazuje se u više navrata kao dvosmislena i preteća, kao zlostavljač i preljubnik, svedočeći o nelagodi i opasnosti probijanja konzervativnih granica u savremenoj kulturi. Junakinje će suočavanje sa sobom, što je možda i osnovna kontroverza filma, ostvariti i u iskustvu sopstvenog homoerotskog impulsa, kao i susreta sa „drugačijim“ muškarcem, starim glumcem koji živi s one strane granice, u Hrvatskoj, u šumi, u kući sa mladim muškim prijateljem i bogatom i tajnovitom bibliotekom. U njegovoj biblioteci će naivna Simona zaviriti i u ljubavne homoerotske crteže jednog poznatog umetnika (u pitanju je Žan Kokto /Jean Cocteau/). Film kroz glavne junakinje svedoči o širem odbacivanju žene koja, bivajući povređena od strane muških figura, protestuje i teži samostalnosti.

Istoričarka umetnosti, novinarka i političarka Majda Širca, državna sekretarka Ministarstva kulture (1997-2000) i ministarka kulture Republike Slovenije (2008-2011), autorka je oko sedamdeset dokumentarnih emisija i više teorijskih eseja i monografija iz istorije kulture, politike i umetnosti filma. Devedesetih godina prošlog veka radila je kao urednica kulturno-informativnog i dokumentarno-umetničkog programa RTV Slovenije. 
U svom novijem dokumentarnom opusu (nakon 2015), Majda Širca gradi jedinstveni autorski svet TV dokumentarnih filmova u produkciji RTV SLO: Žena 1 i 2 (Ženska 1 \& 2, 2016), Sedam grehova $i$ vrlina (Sedem grehov in vrlin, 2017) i Druga koža (2018). Dati filmovi su istorijsko-antropološki filmski eseji izrazito formalističke, možemo reći - visoke ili akademske (neo)modernističke strukture. Navedena dela odlikuju fina intelektualna ironija i radoznala upitanost nad pitanjima „zvanične“ istorije - potisnutog i prikrivenog fašizma i nacizma, veštog medijskog iluzionizma socijalističkog poretka u SFRJ, istorije estetike i utopije ili zbilje ženskih prava, i uopšte slobode ličnosti. Zajednički imenitelj ovih filmova je naratorski glas same Širce, koji u gotovo hipnotičnom ritmu i zvuku, te stručnom i blago ironijskom diskursu, iznosi osvrt na datu temu, bogato ilustrovanu arhivskim i savremenim materijalom. Specifičnost ovih ostvarenja je i istorijski pristup od lokalnog i posebnog, dakle - od slovenačkog i bivšejugoslovenskog, ka globalnom i univerzalnom. Radi se o nenametljivoj, ali nužnoj samosvesti spram sopstvene nacionalne kulture.

Ambiciozan i stilistički besprekoran, sa izvanrednim radom kamere (Jurij Nemec), Sedam grehova i vrlina (2017) - iznenađujuće smelo i lucidno, a nadasve upućeno - dokumentuje, obrađuje i varira klasičan motiv sedam hrišćanskih grehova i vrlina kroz upečatljive epizode iz istorije Slovenije, Jugoslavije i Evrope tokom 20. veka. Asocijativno povezujući pojmove gordosti, pohlepe, zavisti, straha i drugih grehova, te plemenitosti, skromnosti, čednosti, ljubavi i srodnih vrlina sa dokumentarnim materijalima i svedočenjima o političkim i kulturnim utopijama / pokretima, film preispituje neuralgične tačke i bolne epizode oduševljenja diktatorima, socijalističkih zanosa, zločina i nada. Usmeravajući gledaoca na istorijski učestalu lakoću prelaska od ideala do autoritarizma, rata i smrti, film ističe i divne primere iz istorije umetnosti, isprepletene sa ideološkim „preokretima“ od sakralnog ka racionalnom / revolucionarnom, te ulazi u trag mitskim autobusima iz dva jugoslovenska filma (Ko to tamo peva i Okupacija u 26 slika). O svom radu na ovim ostvarenjima svedoči sam Karpo Godina. Prateći početke i krajeve istorijskih utopija i režima kroz splet vrlina i grehova, vidimo priču o atentatima na Musolinija, nekadašnji ponos Titove ratne mornarice, danas poluistruleli Galeb, jedinstveno komponovanu D’Anuncijevu palatu-mauzolej, sa natpisom na točku o „pet smrtnih grehova“, slučaj razdvajanja dečaka od majke Slovenke za vreme Drugog svetskog rata i nacizma, po kome je u UK snimljen i igrani film, projekat „sa- 
vršenog grada "Nove Gorice, crkvu Svetog Martina na Bledu i zgradu posleratne Narodne skupštine u Ljubljani, koje je oslikao isti slikar, te spomen-muzej logora Jasenovac.

Žena 1 i 2 (2015, 2016) i Druga koža (2018) jesu ozbiljno feministički intonirane studije istorije žene, njenog društvenog položaja i njenih prava tokom proteklih nekoliko vekova, uključujući i jugoslovenski socijalizam. Druga koža u navedenom kontekstu uporedno posmatra društvene običaje i istoriju mode, s posebnim osvrtom na ženski rad u okviru ženske i druge mode i tekstilne industrije, kakav inače po pravilu izostaje.

Žena 1 i 2 prati istoriju političkog osvešćivanja žena u Sloveniji u 19. i 20. veku. Prelaz iz 19. u 20. vek u slovenačkom društvu odlikuje pojava više stotina ženskih društava i organizacija, ali i kažnjavanje i ,izopštavanje“ osvešćenih pojedinki. Žene slikarke, kao zapostavljeni „deo“ istorije lepih umetnosti, ${ }^{12}$ takođe se ističu kao spona između obožavanja klasične slike ženske lepote i nevinosti u konzervativnom dobu i razvoja ženske samosvesti i postepenog sticanja veće političke i ekonomske samostalnosti. Film pripoveda najpre o emancipaciji tokom predratnog perioda, kada žene zaposlene $u$ industriji daju svoj doprinos radničkoj borbi za bolje uslove života i rada, ili pak odlaze u svet u emigraciju, a zatim o njihovoj ogromnoj ulozi u narodnooslobodilačkoj revoluciji i socijalizmu, kada žena dobija pravo glasa. Pominje se interesantna činjenica da se kroz modernu istoriju kao žrtve patrijarhalne diskriminacije najviše osećaju upravo žene koje se zalažu za emancipaciju, koje mnogo rade, a bivaju osuđene u javnom životu, kao što je to, uostalom, slučaj i danas.

Teške posledice predrasuda i ženomržnje, njihov odraz na žensko reproduktivno zdravlje i, usled eksploatacije i nerazumevanja, često uskraćeno emotivno blagostanje, te sudbina prvih učiteljica kojima je bilo zabranjeno da se udaju, iznova ukazuju na duboke slojeve društvene i kulturne nepravde učinjene ženi u prošlosti, koje još nisu iščezle i koje loše utiču na živote žena, dece i čitave zajednice. Film Žena 1 i 2 je potpuno pokriven tonski, vizuelno, asocijativno; bogat je i bremenit informacijama i saosećanjem spram protagonistkinja istorijske pozornice 19. i 20. veka i njihovih bližnjih. Film dokazuje da ima sasvim dovoljno objektivnih istraživanja, podataka, arhiva i stručnih svedokinja i svedoka koji mogu detaljno dokumentovati

${ }^{12}$ Važno mesto savremene feminističke teorije jesu studije reprezentacije žene i ženskog tela u klasičnoj umetnosti, zajedno sa otkrivanjem i argumentacijom značaja doprinosa žena kao umetnica u svetskoj istoriji umetnosti, čiji ih doskorašnji kanon po pravilu isključuje pod uticajem patrijarhalne ideologije. 
modernu istoriju žena kao specifikum, te je pravilno i humanistički interpretirati u cilju poboljšanja kvaliteta života svih generacija.

U Drugoj koži, raskošno barokni kvalitet slike i kostim, uz kinetički-montažno uzbudljivo kombinovanje materijala pohranjenog u umetničkim delima klasičnog slikarstva renesanse i baroka i u dokumentarnoj arhivskoj građi iz 20. veka, uokvireni su asketski strogom formom celine filmskog dela, čime se postiže zavidna estetičnost i dinamizam. Od krinoline do savremene visoke mode ( $\mathrm{u}$ filmu nastupa i znameniti kostimograf i modni kreator Alan Hranitelj) podsećamo se i modnih utopija posleratnog slovenačkog i jugoslovenskog filma, saznajemo da je Maribor bio „slovenački Mančester“ $u$ epohi socijalizma, te da su u poslovima šivenja odeće bile zaposlene na hiljade žena. Obrt društva ka konzumerizmu povećao je i potrebu za lepim oblačenjem kod milionskog stanovništva, u kome su svako domaćinstvo i građanka imali svoju „Singericu“, i je podstakao šverc odeće i obuće kao kulturnu praksu. ${ }^{13}$

U navedenim filmovima nastupaju istaknute profesorke univerziteta i umetnice, feminističke teoretičarke i političarke, istoričarke i direktorke muzeja antropologije i slovenačkih gradova, inače ne uvek dovoljno vidljive u široj javnoj sferi: Milica Antić Gaber, Irena Selišnik, Sabina Žnidaršič, Vesna Leskošek, Maca Jogan, Mirjam Hladnik Milharčič, Svetlana Slapšak, Meta Krese, Maja Hren Brvar, Breda Luthar, i druge. Uspostavljajući kritički odnos prema nostalgiji za bivšim epohama i lepotom žene i mode u prošlosti, autorka u ovome i prethodna tri filma uspostavlja zapravo trezveni, kreativni i istraživački odnos prema samoj stvarnosti u svim njenim najznačajnijim dimenzijama - od intimno-psihološke i kolektivno-političke do ukupnosti društvenog i kulturnog življenja.

\section{Literatura}

Daković, Nevena. 2008. Balkan kao (filmski) žanr: slika, tekst, nacija. Beograd : Fakultet dramskih umetnosti : Institut za pozorište, film, radio i televiziju.

Dimitrijević, Andrija i Zdravko Duša (priredili). 2002. Slovenački film na početku milenijuma. Beograd : Dom kulture Studentski grad ; Novi Sad : Kulturni centar.

\footnotetext{
${ }^{13}$ Posebno šverc iz Italije, kao u slučaju švercovanja „kaubojki“ i „džins“ pantalona u Sloveniju i SFRJ do kraja osamdesetih godina prošlog veka.
} 


\section{Kronja
Neke autorske tendencije $\mathrm{u} . .$.}

Germani, Sergej Grmek. 2002. „Slovenački film preko granica“. U Slovenački film na početku milenijuma, prir. Andrija Dimitrijević i Zdravko Duša, 5-7. Beograd : Dom kulture Studentski grad ; Novi Sad : Kulturni centar.

Iordanova, Dina. 2001. Cinema of Flames: Balkan Film, Culture and the Media. London : BFI Publishing.

Iordanova, Dina. 2006. „Introduction“. U Dina Iordanova The Cinema of The Balkans, 1-11. London : Wallflower Press.

Kosanović, Dejan. 2011. Kinematografija i film u Kraljevini SHS/Kraljevini Jugoslaviji: 1918-1941. Beograd : Filmski centar Srbije.

Lipovecki, Žil i Žan Seroa. 2013. Globalni ekran: od filma do smartfona. Novi Sad : Akademska knjiga.

Mazaj, Meta. 2011. Freewheeling on the margins: the discourse of transition in the new Slovenian cinema. Studies in Eastern European Cinema Vol. 2 (1): 7-20.

Pavičić, Jurica. 2011. Postjugoslavenski film: stil i ideologija. Zagreb : Hrvatski filmski savez.

Poro, Antoan. 1990. Enciklopedija psihijatrije. Beograd : Nolit.

Širca, Majda, Ivan Nedoh i Lilijana Stepančič. 2014. Piran $v$ filmu: koprodukcijski časi Slovenije. Piran : Obalne galerije.

Šop, Ljiljana. 2010. Nostalgija i književnost. Sarajevske sveske 29/30: 217228. Dostupno na: http://sveske.ba/en/broj/2930-1(pristupljeno 10. 11. 2018).

Šprah, Andrej. 2012. „Ljubljana je ljubljena: mesto herojinja“. U: Matjaž Klopčič: eseji in pričevanja, ur. Andrej Šprah, 193-223. Ljubljana : Slovenska kinoteka.

Todorova, Marija. 1999. Imaginarni Balkan. Beograd : Bibilioteka XX vek : Čigoja štampa.

Trušnovec, Gorazd. 2002. „Decenija slovenačkog filma“. U Slovenački film na početku milenijuma, prir. Andrija Dimitrijević i Zdravko Duša, 9-28. Beograd : Dom kulture Studentski grad ; Novi Sad : Kulturni centar.

Veb stranice

Dani slovenačkog filma. Dostupno na: https://www.danislovenackogfilma. org/ (pristupljeno 10.11. 2018).

Slovenski filmski center. Maja Weis. Dostupno na: https://www.film-center. si/sl/film-v-sloveniji/filmi/oseba/4568/maja-weiss/ (pristupljeno 10. 11. 2018).

Slovenski filmski center. Film $v$ Sloveniji. Dostupno na: https://www. film-center.si/sl/film-v-sloveniji/ i https://www.film-center.si/sl/ (pristupljeno 10. 11.2018). 
Ivana Kronja

Visoka šola likovnih in uporabnih umetnosti

Beograd, Srbija

i.kronja@yahoo.com

\section{NEKATERE AVTORSKE TEŽNJE V SODOBNEM SLOVENSKEM FILMU: NOSTALGIJA, KRITIKA, ANGAŽMA}

Znanstvena obravnava teme »Nekatere avtorske težnje v sodobnem slovenskem filmu« se ukvarja z izbranimi filmskimi stvaritvami nedavne slovenske filmske produkcije (od konca devetdesetih let prejšnjega stoletja do danes), vključujoč dokumentarne in igrane filme. Cilj prispevka je, da prouči tematske, poetološke in stilske tendence sodobnega slovenskega avtorskega filma, tj. filmske umetnosti, ki se razvija in $\mathrm{v}$ današnji produkciji in filmski estetiki dosega zavidljivo raven profesionalnosti. $\mathrm{Z}$ vidika tematike in stilistike sodobni slovenski film odlikuje prevpraševanje preteklosti in tranzicijskih socialnih tem, h katerim pogosto pristopa $\mathrm{v}$ visoko estetiziranem avtorskem / postmodernem ključu, ali pač skozi neomodernistično poetiko.

Ključne besede: slovenska kinematografija, nostalgija, angažma, socialna grozljivka, filmski stil

Ivana Kronja

College of Fine and Applied Arts

Belgrade, Serbia

i.kronja@yahoo.com

\section{SOME CREATIVE TENDENCIES IN MODERN SLOVENIAN FILM: NOSTALGIA, CRITICISM, ENGAGEMENT}

The paper analyzes selected cinematographic works from the recent Slovenian production (since the late 1990s until present), including both documentary and feature films. It seeks to explore thematic, poetic and stylistic trends in modern Slovenian art film - the art of film that develops and reaches an enviable professional level in terms of production and cinematographic aesthetics. As far as themes and styles are concerned, Slovenian film is marked by the reconsideration of the past and social issues typical of the transition period. They are often interpreted in a highly aestheticized key, with a strong artist's/postmodern imprint, or in the context of a neomodern poetics.

Keywords: Slovenian cinematography, nostalgia, engagement, social horror, cinematographic style 